\title{
Students' mathematical reasoning ability in solving PISA-like mathematics problem COVID-19 context
}

\author{
Ismi Nurazizah, Zulkardi * \\ Department of Mathematics Education, Sriwijaya University, South Sumatra, Indonesia \\ *Correspondence: zulkardi@unsri.ac.id \\ (c) The Author(s) 2022
}

\begin{abstract}
This study aims to use the Pendidikan Matematika Realistik Indonesia (PMRI) approach to measure the mathematical reasoning ability of grade VII students in answering PISA-like mathematics problems on number content in the context of COVID-19. This study employs descriptive research with 34 participants from a junior high school in Palembang, Indonesia. Tests, interviews, and observations were utilized to collect data. The method of analysis adopted is descriptive. Google Meet is used to facilitate learning. Learning the PMRI technique was accomplished in this study by assigning sharing and jumping tasks. That is, assignments for students to discuss with each other have different levels of difficulty, followed by two exam questions. In the context of COVID-19, the test questions are PISAlike maths problems. The results show that students' average mathematical reasoning skill is 63,037 , with mathematical manipulation a common indicator. Most students have exhibited indications for presenting conjectures. However, only a few students have put down indicators for drawing logical conclusions, so drawing logical conclusions is an indicator that students rarely see. Overall, grade VII students' mathematical reasoning skills in answering PISA-like mathematics questions on number material in the context of COVID-19 utilizing the PMRI approach is good since students are used to modeling contextual problems such that mathematical manipulation indicators occur.
\end{abstract}

Keywords: COVID-19; mathematical reasoning ability; PISA; PMRI; number 


\section{Introduction}

The reasoning is a crucial skill that may be used to learn, understand, and solve issues in math and real life (Sofyana \& Kusuma, 2018). Students' reasoning ability is defined as their ability to think in terms of connecting statements or premises whose truth has been established to conclude (Akuba et al., 2020; Asdarina \& Ridha, 2020). The mathematical literacy ability tested in PISA includes reasoning mathematically (OECD, 2019). One of the materials that involve mathematical reasoning abilities in studying is number material (NCTM, 2000). Additionally, students should master the number material because it is a vital component of life. So the number is an essential material to learn. Numbers, especially integers, are taught in 7th-grade so that students' mathematical reasoning abilities in number material can be used to define students' reasoning abilities in more challenging subjects (Purwanti et al., 2020).

However, as seen by the results of the 2018 PISA, Indonesian students' mathematical reasoning ability is still relatively low; the mathematics score of Indonesian students is 379 . It is a lower result than in 2015 when Indonesia received a 386 in maths (OECD, 2019). One of the materials tested in PISA is number (OECD, 2109). However, because teachers frequently ask low-level routine questions, students are not used to addressing contextual problems such as PISA (Nusantara et al., 2020a). Students' low thinking ability is also caused by a lack of ability to comprehend or study topics thoroughly and errors in computations (Amalia \& Hadi, 2020; Sofyana \& Kusuma, 2018).

Students need to be familiar with PISA-like mathematics problems (Nusantara et al., 2020b). Giving students a PISA-like mathematics problem will acquaint them with working on PISA questions, which will help them enhance their reasoning skills (Azizah et al., 2017). Students' mathematical literacy, which means their reasoning, can be improved by asking questions with valid and practical PISA-like maths problems (Zulkardi \& Kohar, 2018).

The context that is close to students and is a hot topic currently being discussed is the context of COVID-19 (Saputri et al., 2020). Situations like the number of deaths and incidents of spread are frequently reported in the media. This environment is ideal for learning mathematics (Nusantara et al., 2021). It's believed that through learning about the current COVID issue, students will be able to grasp conflict, what COVID-19 is, how it is disseminated, and how students can tell if it's fact or hoax. There are already a plethora of materials relating to COVID-19, such as the proliferation of cases across Indonesia (Prabowo \& Dahlan, 2020). As a result, the teacher can use that context to present PISA-like maths problems during the learning process.

The applied learning method or strategy impacts students' thinking abilities (Zulkardi, 2002). PMRI is a teaching method based on real-life situations that students have encountered (Zulkardi \& Putri, 2010). In this instance, PMRI may be a viable option for improving the learning process and outcomes since students will be able to expand their knowledge and understand the concepts in that content (Manik, 2021).

This study is linked to a previous study that looked at the relationship between using the PMRI approach to improve students' mathematical reasoning abilities in number patterns (Octriana, 2019) and students' reasoning abilities in solving PISA equivalent questions with 
geometric content (Octriana, 2019). (Asdarina \& Ridha, 2020). However, there has been no research on student's mathematical reasoning abilities in solving PISA-like mathematics problems in the context of COVID-19 using the PMRI approach. In this regard, the researchers are interested in researching to gain an overview of students' mathematical reasoning abilities in solving PISA-like mathematics problems in the context of COVID-19 using the PMRI approach on class VII number material.

\section{Methods}

This descriptive study uses the PMRI approach to determine students' mathematical reasoning abilities in solving PISA-like mathematics problems on the COVID-19 context number material. The participants in this study were 34 students consisting of 20 male students and 14 female students from SMP Srijaya Negara Palembang's class VII.B in the odd semester of the 2021/2022 academic year. Data was gathered using essay test questions as many as two items, observations, and interviews with three students with different abilities, namely high, medium, and low. The test consists of two items in the form of a description of the test question. Number one has a level of difficulty, namely level two equivalent to $C 3$, while question number two is level three equivalent to C4. The lecturer of Sriwijaya University, the doctoral student of Sriwijaya University, and the teacher of SMP Srijaya Negara Palembang all validated the research instrument. Validation results for the three validators The images chosen must be real data, problem-solving must include at least two strategies, and the question sentence editor must be adjusted to the level of difficulty, among other things. Following that, the researcher conducted one-on-one and small group trials, with the results for question number two being changed from "amount" to "total."

The results of student answer will be analyzed using the following scoring guidelines.

Table 1. Scoring guidlines

\begin{tabular}{cl}
\hline Score & \multicolumn{1}{c}{ Reasoning Indicator } \\
\hline 4 & Perfect answer, completion is given completely and correctly \\
3 & The answer are correct, but the solution given contains one significant error \\
2 & $\begin{array}{l}\text { The answer is almost correct, but solution given contains more than one significant } \\
\text { error or deficit } \\
\text { The answer is wrong, the solution is not completely resolved but contains at least one } \\
\text { valid argument } \\
\text { The answer is wrong, the solution is based on process or argument that is wrong or } \\
\text { contains no response at all }\end{array}$
\end{tabular}

The observation data were descriptively analyzed, and researchers saw which students were active in the learning process and then presented them in the table. The interviews data were analyzed descriptively, and researchers listened to the student's answers about how they answered the questions.

The test's purpose was to determine which category of students' mathematical reasoning abilities in problem-solving fell into. Using the PMRI approach, observations were made to see what indicators emerged and students did while learning (Anggraini \& Zulkardi, 2020). Learning using the PMRI approach begins by giving sharing tasks that enable students to 
discuss with each other to solve the problem with tiered questions. Then, students are given jumping tasks to use their knowledge and discuss with friends how to solve questions that have a higher level of difficulty than sharing tasks. From the results of students' answers, students begin to see whether their reasoning abilities are approximately good or not. The next step is to test student's mathematical reasoning abilities. While interviews were conducted to confirm answers to student test results and provide data to support test results, they were also conducted to confirm the answers to student test results (Saputri et al., 2017; Anggraini \& Zulkardi, 2020). The type of data analysis that was used was descriptive. In this study, the following are indicators and descriptors of mathematical reasoning abilities adopted from Dikdasmen Depdiknas No 506/C/PP/2004 date November 11, 2004, regarding the development of junior high school students.

Table 2. Mathematical reasoning ability indicator

\begin{tabular}{lll}
\hline \multicolumn{1}{c}{ Indicator } & \multicolumn{1}{c}{ Descriptor } \\
\hline Submit a conjecture & $\bullet$ & $\begin{array}{l}\text { Able to write what is known and asked from } \\
\text { pictures and questions }\end{array}$ \\
\hline Mathematical & $\bullet$ & $\begin{array}{l}\text { Able to translate problems in sentence form into } \\
\text { mathematical form } \\
\text { Manipulation }\end{array}$ \\
& - & Able to solve problems based on assumptions \\
\hline Drawing Logical & $\bullet$ & $\begin{array}{l}\text { Able to write logical conclusion in accordance } \\
\text { with the problem }\end{array}$ \\
\hline
\end{tabular}

Table 2 contains indicators and descriptors of mathematical reasoning ability used in this study and has been adapted to the number material.

\section{Results}

Starting with the problem of sharing tasks and jumping tasks, the learning is carried out using the PMRI approach, and the test questions are as in Figure 1. Figure 1 depicts the number one test question, which has a difficulty level of level two equal to C3. As of June 28, 2021, the data in the image represents death data for Indonesian health workers as a result of COVID19. Between March 2020 and June 2021, students must calculate the number of deaths caused by COVID-19 among health practitioners. 
Take a look at the illustration below.

COVID-19 causes the death of Indonesian health workers

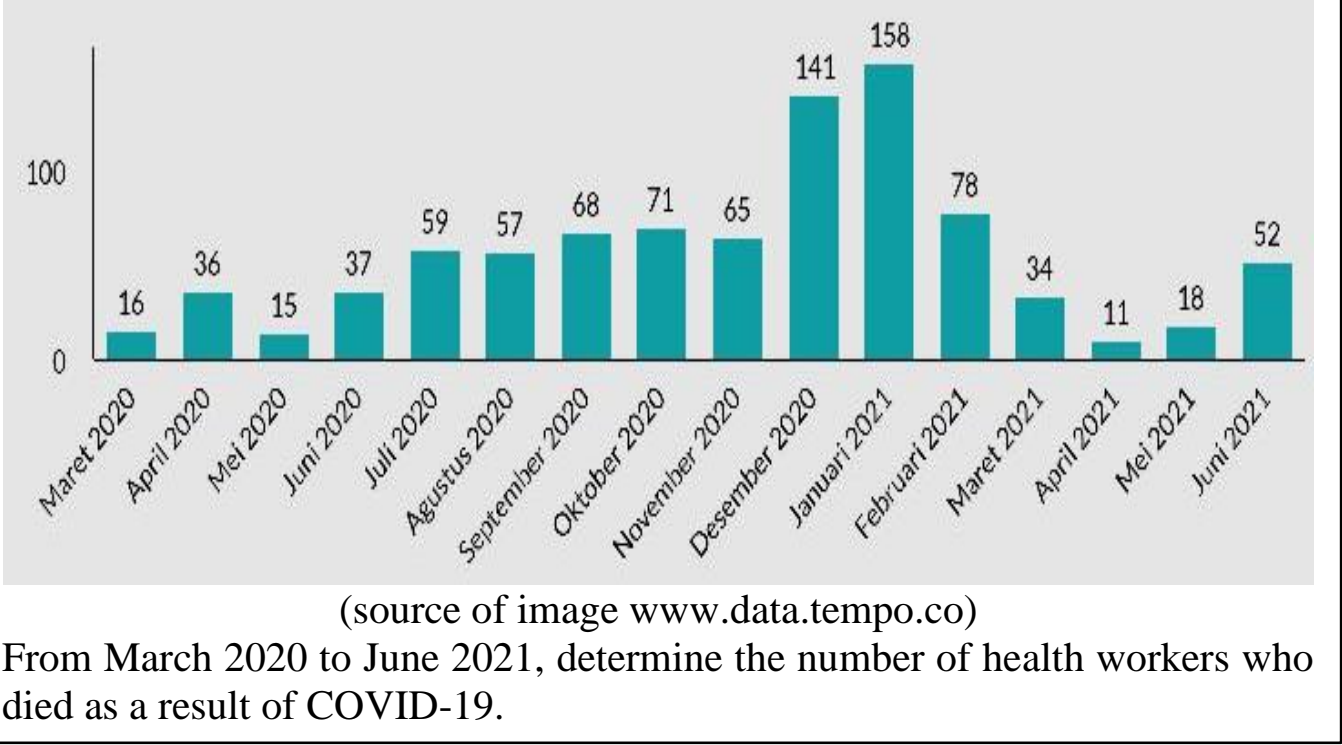

Figure 1. Test question number 1

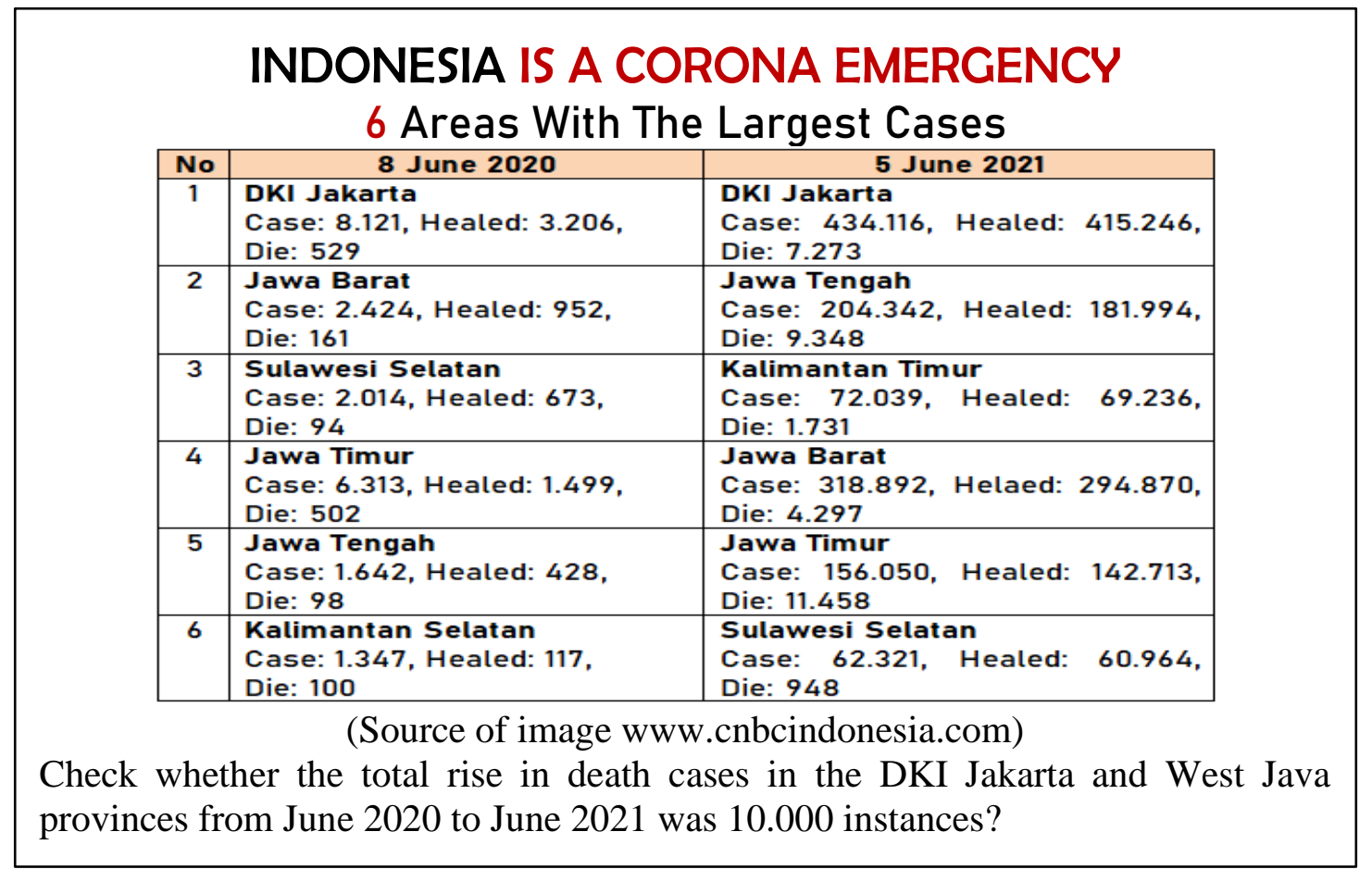

Figure 2. Test question number 2

Figure 2 depicts the number two test question, which has a difficulty level of level three, equivalent to C4. In June 2020 and June 2021, the picture of Indonesia's corona emergency indicates six regions with the most incidents. Students must verify whether the cumulative rise in mortality cases in DKI Jakarta and West Java Provinces from June 2020 to June 2021 reached 10,000. Here are some of the students' responses. 


\section{AA's answers (high ability student)}

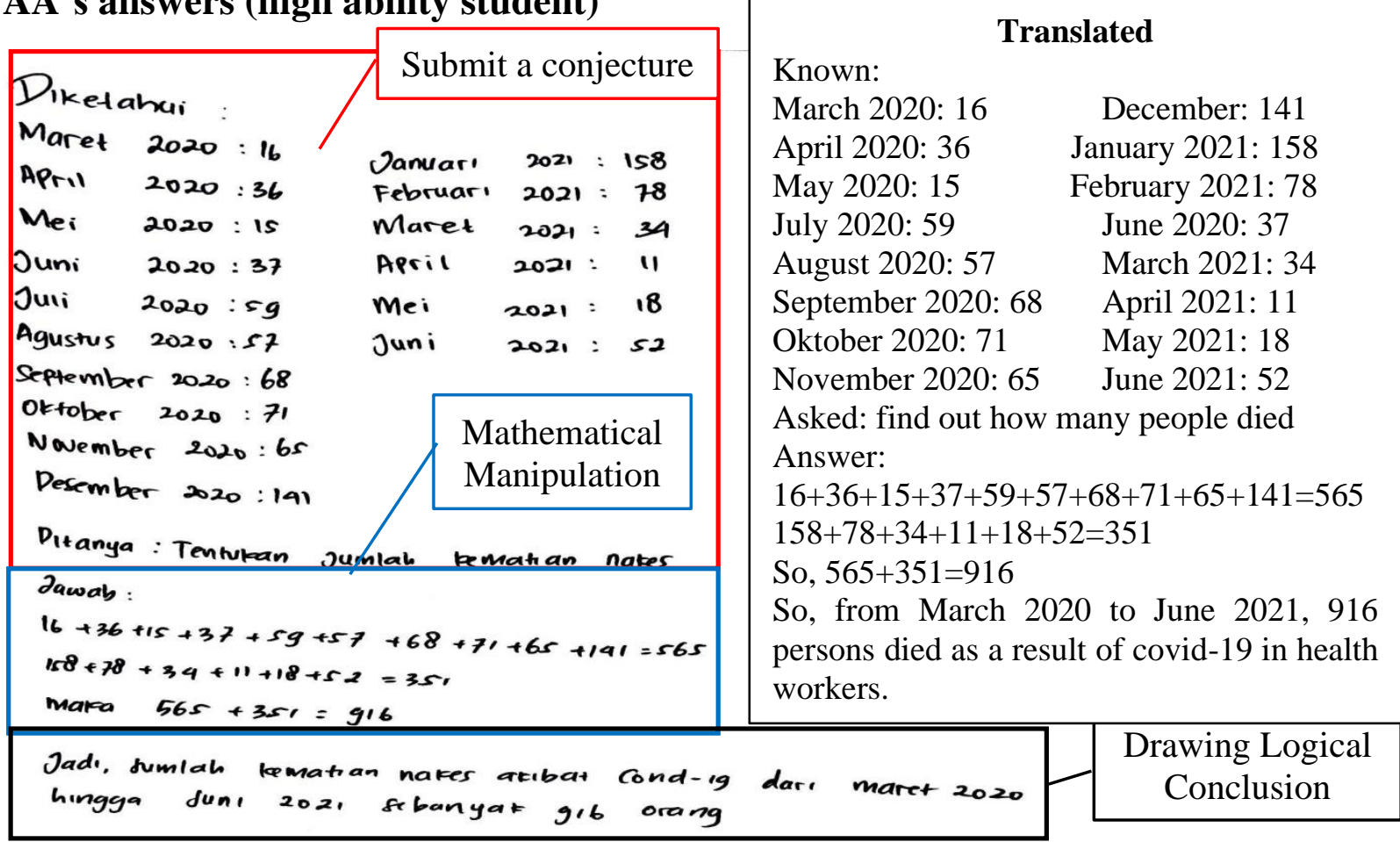

Figure 3. AA's answer for the question number 1

Figure 3 shows that students comprehend the information in the image and the meaning of the problem, resulting in indicators making assumptions, manipulating mathematics, and drawing logical conclusions. Students receive a score of 12 on question number 1 . AA is one of the students who pay attention and is not afraid to ask questions even during learning.

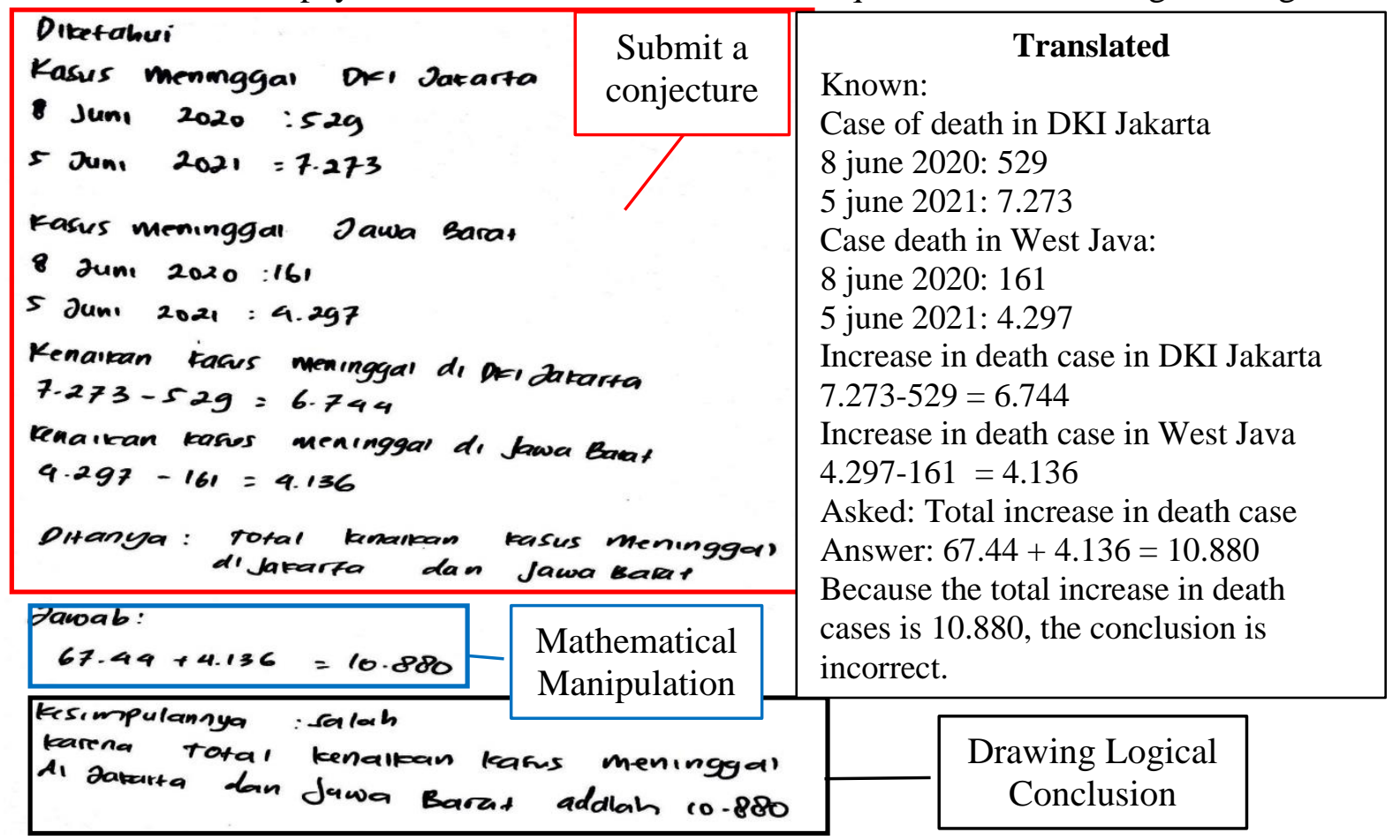

Figure 4. AA's Answer for the question number 2 
Figure 4 shows that students comprehend the question's content and can write down everything known and asked in its entirety. As a result, he receives a score of 4 . The final step, checking for increases in the two provinces, adding them together, and receiving a score of 4 , is likewise right. The conclusion is also correct, earning a score of four. As a result, the overall score is 12 .

\section{ST's answer (medium ability student) $\quad$ Submit a conjecture}

\begin{tabular}{|c|c|}
\hline 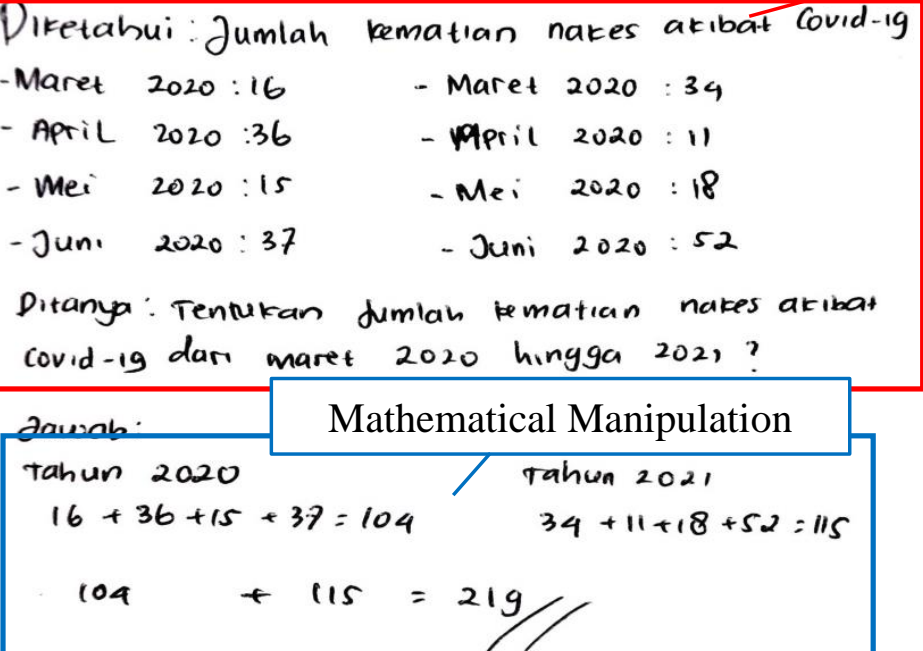 & $\begin{array}{l}\text { Translated } \\
\text { Known: Number of death } \\
\text { from healtg workers due } \\
\text { to COVID-19 } \\
\text { In } 2020 \quad \text { In } 2021 \\
\text { March }=16, \text { March }=34 \\
\text { April }=36, \text { April }=11 \\
\text { May = 15, May = } 18 \\
\text { June = 37 June = 52 } \\
\text { Asked: determine the } \\
\text { number of deaths from } \\
\text { health workers due to } \\
\text { COVID-19 from march } \\
2020 \text { untill june } 2021\end{array}$ \\
\hline
\end{tabular}

Figure 5. ST's answer from the question number 1

Based on the responses of students and interviews, it appears that ST is misinterpreting the questions, resulting in incorrect solutions at the end. The question covers the period from March 2020 to June 2021, yet ST only writes from March 2020 to June 2020, then from March 2021 to June 2021 in the second part. Meanwhile, the period from July 2020 to February 2021 has not been written. The researcher came to the conclusion that ST did not read the questions carefully or could not properly analyze them. Her mathematical manipulation abilities are already strong, it's only that the outputs are incorrect due to the inadequate data. ST does not include a conclusion in the results section, only line two. Based on the foregoing analysis, the researcher assigns a 2 to the indicator of making claims, a 3 to the indicator of mathematical manipulation, and a 0 to the indicator of drawing logical conclusions. As a result, the ST score attained is 5 .

Figure 6 and results of student interviews show that ST knows what they know and are asked about the questions. She meets the indicator of submitting an assumption with a score of four. However, he was inaccurate when it came to math because, rather than looking for an increase in death cases in each province, she added death cases to the two provinces every year. She got one for it. She determined that it was accurate even if the result he received was not 10,000 examples to draw a reasonable conclusion. She then receives a score of zero. She is awarded a total of 5 points. 


\begin{tabular}{|c|c|}
\hline & \multirow{9}{*}{$\begin{array}{l}\quad \text { Translated } \\
\text { Known: } \\
\text {-Death case in Jakarta } 2020=529 \\
\text {-Death case in West Java } 2020=161 \\
\text {-Death case in Jakarta } 2021=7.273 \\
\text {-Death case in West Java } 2021=4.297 \\
\text { Asked: } \\
\text { Check whether the total rise in death } \\
\text { cases in the DKI Jakarta and West Java } \\
\text { provinces from June } 2020 \text { to June } 2021 \\
\text { was } 10.000 \text { instances? } \\
\text { Answer: True } \\
\text { Death case } 2020 \\
529+161=690\end{array}$} \\
\hline Diketahui & \\
\hline - Kasus meninggal di Jakarta $2020=529$ & \\
\hline Kasus meninggal di Jawd barat $2020=161$ & \\
\hline - kasus meninggal di jakarta $2021=7.273$ & \\
\hline - kasus meninggal di Jawa Barat $2021=4.297$ & \\
\hline Submit a conjecture & \\
\hline $\begin{array}{l}\text { Ditanya: } \\
\text { Apakah benar Total knaikan kasus meninggal } \\
\text { yang kgadi di Provinsi DFI Jakaita dan Jawa Burat } \\
\text { Selama bulan Juni tohun } 2020 \text { hingga belan Juni } \\
2021 \text { sebanyak } 10000 \text { kasus? }\end{array}$ & \\
\hline Mathematical Manipulation & \\
\hline Dusawab: Benar / kasus me & $\begin{array}{l}\text { Death case } 2021 \\
26273+4297=1.1570\end{array}$ \\
\hline $\begin{array}{ll}h_{k 1} \text { Jakarta } \quad 529 \\
161 \\
\end{array}$ & $\begin{array}{l}7273 \\
4297\end{array}$ \\
\hline 690 & \\
\hline
\end{tabular}

Figure 6. ST's answer from the question number 2

\section{RR's answer (low ability student)}

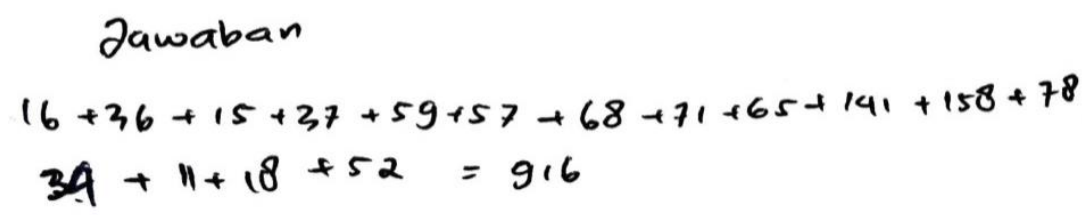

Figure 7. RR's Answer from the question number 1

It indicates that students comprehend the meaning of the questions based on the images and the findings of interviews with students. It is only that he did not write down everything that was known and requested; instead, he answered the problem right away by writing down the facts in an addition operation. As a result, the student does not appear to be submitting his conjecture; instead, the student appears to be manipulating numbers. Because the signs for generating logical conclusions are also absent, they receive a 4 out of a possible 5 .

Then, in response to question 2, RR simply wrote the word "yes" in the response. The signal in this example reveals that RR draws judgments, but she does so without supporting evidence. She seemed to be oblivious to the meaning of the inquiry. Indicators are not used to make conjectures, and mathematical manipulations are not used. Because the response is incorrect and is not supported by evidence, the score is 0 , and she receives a score of 0 in question 2.

Only 14 of the 34 students collected responses to the tests. It is because many kids do not own cell phones and rely on their parents' property to complete their assignments, making it difficult to complete them. The indications' appearance can be seen in the accompanying table, which is based on the responses of 14 students. 
Table 3. The origin of mathematical reasoning ability indicators

\begin{tabular}{lcc}
\hline \multicolumn{1}{c}{ Indicator } & \multicolumn{2}{c}{ Total student who meet } \\
\cline { 2 - 3 } & $\begin{array}{c}\text { Question test } \\
\text { number 1 }\end{array}$ & $\begin{array}{c}\text { Question test } \\
\text { number 2 }\end{array}$ \\
\hline Submit a Conjecture & 10 & 11 \\
Mathematical Manipulation & 13 & 12 \\
Drawing Logical Conclusion & 6 & 8 \\
\hline
\end{tabular}

According to table 3, the indicator that emerges the most frequently from the two test questions is mathematical manipulation, which received responses from 13 people for question one and 12 people for question two. The scores of all students' replies were then calculated and arranged into table 4 below.

Table 4. The qualitative value of mathematical reasoning ability

Note:

\begin{tabular}{lccc}
\hline Score & $\mathbf{f}_{1}$ & $\mathbf{f}_{\mathbf{2}}$ & $\mathbf{f}_{\text {tot }}$ \\
\hline $81-100$ & 5 & 7 & 12 \\
$61-80$ & 3 & 1 & 4 \\
$41-60$ & 1 & 2 & 3 \\
$21-40$ & 5 & 0 & 5 \\
$0-20$ & 1 & 2 & 3 \\
\hline
\end{tabular}

f1: Number of students in question number 1

$\mathrm{f} 2$ : Number of students in question number 2

ftot: $\mathrm{f} 1+\mathrm{f} 2$

According to table 4, the top five students on question one have the highest score, while the top seven students have the highest score on question two. The most people are in question two, which has the lowest score, 2 people.

Table 5. Students' average mathematical reasoning abilities

\begin{tabular}{|c|c|c|c|c|}
\hline Score & ftot & $\mathbf{X}_{\mathbf{i}}$ & $f_{\text {tot. }} x_{i}$ & Average \\
\hline $81-100$ & 12 & 90,5 & 1086 & 63,037 \\
\hline $61-80$ & 4 & 70,5 & 282 & \\
\hline $41-60$ & 3 & 50,5 & 151,5 & \\
\hline $21-40$ & 5 & 30,5 & 152,5 & \\
\hline $0-20$ & 3 & 10 & 30 & \\
\hline Total & 27 & & 1702 & \\
\hline
\end{tabular}

According to table 5, the average mathematical reasoning ability of 7th-grade students in solving PISA-like mathematics problems on the COVID-19 context number material after implementing the PMRI approach learning indicates that the students' mathematical reasoning abilities are classified as good.

\section{Discussion}

According to the study's findings, the analysis of students' mathematical reasoning abilities that emerged after learning with PISA-like mathematics problems was applied to the COVID- 
19 context number material using the PMRI approach, according to the study's findings. The following is a more detailed explanation of the indications identified in this research.

\section{Submit a conjecture}

The indication that submitting a conjecture can be described as appearing in the second order. It is because most students displayed the indicator, with only a few students failing to write it down. When the indication presenting conjectures appears, students understand the question by putting down what they know and asking questions based on illustrations and questions. After that, the learner makes an educated assumption about the problem's solution, which leads to mathematical manipulation. Real data or graphics also influence students' responses to problems. According to Zulkardi et al. (2020), some students read the questions first, then look at illustrations, tables, or count all the data, and so on.

\section{Mathematical manipulation}

The indicator that occurs the most in this investigation is mathematical manipulation. Students can convert phrases into mathematical forms and then answer problems using assumptions or what is known and asked from the questions. Even if some students cannot write down what is known and asked, they can solve the problem using arithmetic procedures, even if the solution is not entirely correct. Wulandari et al. (2016) said that this means that students are used to transforming real-world situations into mathematical problems.

\section{Drawing logical conclusion}

Many students fail to write conclusions from the issues they have solved in this indicator. Line two in the answer section on mathematical manipulation is frequently used by students. As a result, after receiving an answer, students line up the two responses to signify that they have concluded. When the indicator should draw a logical conclusion, it appears if the student writes a new statement indicating that sentences are a conclusion from the calculation results (Afnadi, 2016). Some students perform their calculations accurately but come to the incorrect conclusion, which contradicts the data and the questions asked.

Because the teacher directed them, the students appeared to understand the context of COVID-19 when they were studying. Bidasari (2017), PISA-like mathematics problem quantity content, has a potential effect on junior high school students. Fauziah et al. (2017) discovered that using the PMRI approach to learning made it easier for students to understand and learn new things. Students can expand their knowledge and understand the principles in the content they are studying (Manik, 2021). PMRI, according to Octriana et al. (2019), can help students grow and improve their mathematical reasoning indirectly.

However, some students are less engaged in the learning process due to online learning. Due to quotas, networks, parents using cellphones, low batteries, and other factors, many children are passive and do not respond during learning and group discussions. Only 14 students collect test answers as a result of this. Sholichin et al. (2021) found that many students could not participate in learning because of unstable networks, low cellphone 
batteries during class, and a lack of internet capacity.

Aside from the online learning issue, students still require a significant amount of time due to the constraints of researchers who only teach one meeting and immediately deliver test questions for the second meeting, causing students to be unfamiliar with learning to answer problems in the context of COVID-19. As a result, learning that leads to mathematical thinking requires a significant amount of time.

Despite the challenges, the findings of this study demonstrate that students' average mathematical reasoning ability is 63,037 , which is considered good, with mathematical manipulation as an indicator that frequently arises. Students' reasoning abilities were likewise classified as good when using the PMRI technique, according to Nisa et al. (2019). In junior high schools, PMRI could be an alternative learning model (Kusumaningrum, 2016).

For future research, pay attention to the allocation of time used during learning. Then, for the researchers and the students to better prepare all the necessities for online learning, such as internet and network quotas.

\section{Conclusion}

The mathematical reasoning ability of grade VII students in solving PISA-like mathematics problems on the COVID-19 context number material using the PMRI approach is good, according to the research results, because students are used to modeling contextual problems so that indicators of mathematical manipulation appear. Students' understanding of cases of spread and the current situation of Indonesia can be increased by asking questions based on COVID-19 and taught utilizing the PMRI approach. However, this study has some drawbacks, including a lack of lesson hours due to online learning, and the questions used are of a pretty high difficulty level.

\section{Acknowledgment}

Sriwijaya University Grant in 2021 sponsored the publication of this work, which was approved by Rector's Decree Number: 0014/UN9/SK.LP2M.PT/2021 on May 25, 2021. In addition, thanks to Mrs. Elika Kurniadi, S.Pd., M.Sc., as validator, Mr. Duano Sapta Nusantara, S.Pd., as validator and for providing input and suggestions during the writing of this article, and Mrs. Lipa Meisinta, S.Pd., as validator and model teacher, and students of class VII.B SMP Srijaya Negara Palembang who were willing to be subjects in this research.

\section{Conflicts of Interest}

The authors state that the publication of this work does not include any conflicts of interest. Furthermore, the writers have comprehensively addressed ethical issues such as plagiarism, misconduct, data fabrication and/or falsification, multiple publishing and/or submission, and redundancy. 


\section{References}

Afandi, A. (2016). Junior high school student's deductive reasoning in solving geometric problems based on gender differences. Education and Human Development Journal, 1(1), 9-21. https://doi.org/10.33086/ehdj.v1i1.284

Akuba, S. F., Purnamasari, D., \& Firdaus, R. (2020). The effect of reasoning ability, selfefficacy and problem-solving ability on mastery of mathematical concepts. National Journal of Mathematics Education, 4(1), 44-60. https://dx.doi.org/10.33603/jnpm.v4il.2827

Amalia, D. \& Hadi, W. (2020). Analysis of student errors in solving hots questions based on mathematical reasoning abilities. Journal of Mathematics and Mathematics Education, 4(1), 219-236. https://doi.org/10.36526/tr.v4i1.904

Anggraini, E. \& Zulkardi. (2020). Kemampuan berpikir kreatif siswa dalam mem-posingmasalah menggunakan pendekatan pendidikan matematika realistik Indonesia [Students' creative thinking ability in posing problems using the Indonesian Realistic Mathematics Education Approach]. Jurnal Elemen, 6(2), 167-182. https://doi.org/10.29408/jel.v6i2.1857

Asdarina, O. \& Rida, M. (2020). Analysis of students' mathematical reasoning ability in solving problems equivalent to PISA geometry content. Numeracy, 7(2), 192-206. https://doi.org/10.46244/numeracy.v7i2.1167

Azizah, R. F, Sunardi, \& Kurniati, D. (2017). Mathematical reasoning in solving PISA questions for 15 year old students at SMA Negeri 1 Jember. Kadikma Journal, 8(1), 97104.

Bidasari, F. (2017). Development of PISA model math problems on quantity content to measure the mathematical problem-solving ability of junior high school. Jurnal Gantang, 11(1), 63-78. https://doi.org/10.31629/jg.v2i1.59

Depdiknas. (2004). Regulation of director general of primary and secondary education No. 506/CPP/2004 date November 11, 2004, regarding the assessment of the development of junior high school students. Dirjen Dikdasmen Depdiknas.

Fauziah, Putri, R. I. I., Zulkardi, \& Somakim (2017). Primary school student teacher's perception to Indonesian realistic mathematics education (PMRI) instruction. Journal of Physics: Conference Series, 943(1), Article 012044. https://doi.org/10.1088/17426596/943/1/012044

Kusumaningrum, D. S. (2016). Improving reasoning ability and independent mathematics learning through Indonesian realistic mathematics education (PMRI) for junior high school students. Journal of Buana Ilmu, 1(1), 10-20. https://doi.org/10.36805/bi.v1i1.94

Manik, E. (2021). Ethnomathematics and realistic mathematics education. Proceedings of the Ethnomathematics Webinar. (pp. 41-50). University of HKBP Nummensen. https://easychair.org/publications/preprint/J11f

National Council of Teachers of Mathematics. (2000). Principles and standards for school mathematics. Reston, VA.

Nusantara, D. S., Zulkardi, \& Putri, R. I. I. (2020a). Designing PISA-like mathematics problems in the COVID-19 pandemic (PISAComat). Journal of Physics Conference Series, 1657(1), Article 012057. https://doi.org/10.1088/1742-6596/1657/1/012057

Nusantara, D.S, Zulkardi, \& Putri, R. I. I. (2020b). Designing PISA-like mathematics problem relating change and relationship using physical distancing context. Journal of Physics Conference Series, 1663(1), Article 012004.https://doi.org/10.1088/1742$\underline{6596 / 1663 / 1 / 012004}$ 
Nusantara, D. S., Zulkardi \& Putri, R. I. I. (2021). Designing PISA-like mathematics task Using a COVID-19 context (PISAComat). Journal on Mathematics Education, 12(2), 349-364. https://doi.org/10.22342/jme.12.2.13181.349-364

Octriana, I., Putri, R. I. I., \& Nurjannah. (2019). Students' mathematical reasoning in learning number patterns using PMRI and LSLC. Journal of Mathematics Education, 13(2), 131142. https://doi.org/10.22342/jpm.13.2.6714.131-142

OECD. (2019). PISA 2018 assessment and analytical framework. OECD Publishing. https://www.oecd.org/education/pisa-2018-assesment-and-analytical-frameworkb25efab8-en.htm

Prabowo, A. \& Dahlan, J. A. (2020). Pengembangan tes matematika dengan konteks COVID19 untuk siswa SMP/MTs kelas VIII [Development of math tests in the context of covid-19 for class VIII SMP/MTs students]. Jurnal Elemen, 6(2), 302-317. https://doi.org/10.29408/jel.v6i2.2115

Purwanti, S., Syofiana, M., \& Risnanosanti. (2020). Soal tentang bilangan bulat untuk mengukur kemampuan penalaran matematis [Question about integers to measure ability mathematical reasoning]. Jurnal Pendidikan Matematika Raflesia, 5(2), 145-152. https://ejournal.unib.ac.id/index.php/jpmr/article/view/11449

Saputri, I., Susanti, E., \& Aisyah, N. (2017). Kemampuan penalaran matematis siswa menggunakan pendekatan metaphorical thinking pada materi perbandingan kelas VIII di SMPN 1 Indralaya Utara [The students' mathematical reasoning ability uses a metaphorical thinking approach in comparison material for class VIII at SMPN 1 Indralaya Utara]. Jurnal Elemen, 3(1), 15-24. https://doi.org/10.29408/jel.v3i1.302

Saputri, N. W., Turidho, A., Zulkardi, Z., Darmawijoyo, \& Somakim. (2020). The design of PISA questions contains uncertainty and data in the context of the spread of COVID-19. $\begin{array}{llll}\text { Journal of Mathematics Education, } & 8(2), & 106-118 .\end{array}$ https://doi.org/10.20527/edumat.v8i2.8564

Sholichin, M., Zulyusri, Lufri, \& Razak, A. (2021). Analysis of online learning constraints during the COVID-29 pandemic in science subjects at SMPN 1 Bayung Lencir. Scientific Journal of Biology Education, 7(2), 163-168.

Sofyana, U. M. \& Kusuma, A. B. (2018). Efforts to improve students' mathematical reasoning skills use generative learning in class VII SMP Muhammadiyah Kaliwiro. Journal of Mathematics Didactic Research, 2(2), 11-23. https://doi.org/10.30659/kontinu.2.1.14-29

Wulandari, W., Darmawijoyo, D., \& Hartono, Y. (2016). Influence mathematics modeling approach on argumentation skills class VIII SMP negeri 15 Palembang. Journal of Education Sriwijaya $\quad$ Mathematics, $10(1), \quad 114-126$. https://doi.org/10.22342/jpm.10.1.3292.114-126

Zulkardi \& Kohar, A., W. (2018). Designing PISA-like mathematics tasks in Indonesia : Experience and Challenges. Journal of Physics: Conference Series, 947(1), Article 012015. https://doi.org/10.1088/1742-6596/947/1/012015

Zulkardi \& Putri, R. I. I. (2010). Development of a support blog to help Indonesian mathematics students and teachers learn Indonesian Realistic Mathematics Education (PMRI). Journal of Educational Engineering Innovation (JIPP), 2(1), 1-24. https://repository.unsri.ac.id/id/eprint/6777

Zulkardi, Meryansumayeka, Putri, R. I. I., Alwi, Z., Nusantara, D. S., Ambarita, S. M., Maharani, Y., \& Puspitasari, L. (2020). How students work with PISA-like mathematical tasks using COVID-19 context. Journal on Mathematics Education, 11(3), 405-416. https://doi.org/10.22342/jme.11.3.12915.405-416

Zulkardi, Z. (2002). Developing a learning environment on realistic mathematics education for Indonesian student teachers [Unpublished Doctoral Dissertation]. University of Twente. https://doc.utwente.n1/58718/1/thesis_Zulkardi.pdf 